\title{
FCRL5 wt Allele
}

National Cancer Institute

\section{Source}

National Cancer Institute. FCRL5 wt Allele. NCI Thesaurus. Code C123873.

Human FCRL5 wild-type allele is located in the vicinity of $1 \mathrm{q} 21$ and is approximately $39 \mathrm{~kb}$ in length. This allele, which encodes Fc receptor-like protein 5, may be involved in the modulation of B-cell development and functionality. 